\title{
Tropospheric ozone (TOR) trend over three major inland Indian cities: Delhi, Hyderabad and Bangalore
}

\author{
Pavan S. Kulkarni ${ }^{1}$, Sachin D. Ghude ${ }^{2}$, and D. Bortoli ${ }^{1,3}$ \\ ${ }^{1}$ Geophysics Centre of Evora (CGE), University of E' vora, 7000 E' vora, Portugal \\ ${ }^{2}$ Indian Institute of Tropical Meteorology, Pune, 411008, India \\ ${ }^{3}$ Institute for Atmospheric Science and Climate (ISAC-CNR), Bologna, Italy \\ Received: 13 July 2010 - Revised: 26 August 2010 - Accepted: 13 September 2010 - Published: 12 October 2010
}

\begin{abstract}
An analysis of tropospheric column ozone using the NASA Langley TOR data during 1979-2005 has been done to investigate the trend over major Indian cities Delhi, Hyderabad and Bangalore. India was under social democratic-based policies before 1990s. Economic Liberalization began in nineties which lead to a significant growth in industrial, energy and transport sectors in major cities. Our analysis shows that there is a systematic increase in the number of months with higher tropospheric ozone values after 1990. A comparison of TOR climatology before and after 1990 over these cities shows evidence of increase in the tropospheric ozone after 1990. Trend obtained from the model shows significant change during monsoon over Delhi and during pre-monsoon and post-monsoon over Hyderabad and Bangalore. The present analysis using TOR technique demonstrates the TOR potential to detect changes in tropospheric ozone over large cities which are impacted by large anthropogenic pollution.
\end{abstract}

Keywords. Atmospheric composition and structure (Pollution-urban and regional)

\section{Introduction}

Tropospheric ozone $\left(\mathrm{O}_{3}\right)$ is one of the most important greenhouse gases (Mickley et al., 2001) and contributes to global warming and climate change. Long-term changes in tropospheric ozone show a complex pattern over the globe that, in some cases, are driven by regional influences. High amounts of volatile organic compounds (VOCs) and $\mathrm{NO}_{\mathrm{x}}$ from industrial and traffic emissions lead to a fairly high concentration of surface ozone over the industrial cities (Sillman et al., 1990) and can accumulate to a hazardous level during

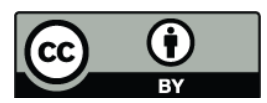

Correspondence to: Pavan S. Kulkarni (pavannpl@yahoo.co.in) favourable meteorological conditions (Jain et al., 2005). It is now a major environmental concern in many big cities of the world, with current concentrations being high enough to harm human health over wide areas (Klumpp et al., 2006a, b; Beig et al., 2008; Ghude et al., 2009). Therefore, the temporal and spatial distribution of tropospheric $\mathrm{O}_{3}$ and the factors controlling its distribution have been a focus of atmospheric chemistry research.

While numerous studies have been conducted in Europe, North America, and Japan (Logan, 1985, 1994; Liu et al., 1987; Oltmans et al., 1998; Monks, 2000; Akimoto et al., 1994; Pochanart et al., 2002), there is limited knowledge of the temporal and spatial distribution of tropospheric $\mathrm{O}_{3}$ in India where rapid urbanization and industrial developments have been taken place in the latest decades. Recently available satellite data have shown an increasing column concentration of nitrogen dioxide, a precursor to $\mathrm{O}_{3}$, over major industrial zones of India (Ghude et al., 2008, 2009) as well as over rural areas during the onset of rainy season (Ghude et al., 2010). Available few scattered ground-based measurements within India have shown frequent $\mathrm{O}_{3}$ pollution during photo-chemically active seasons in urban areas (Naja and Lal, 2002; Jain et al., 2005; Ghude et al., 2006). However, all these studies seldom describe long term changes in tropospheric ozone, except over cities like Ahamadebad and Delhi (Lal et al., 2002; Ghude et al., 2009) where increasing daytime surface ozone has been reported. Hence, more efforts are needed to understand the temporal evaluation of tropospheric ozone over the large cities with respect to the increasing demand of energy consumptions and rapid urbanization. Satellite observations of ozone (total column, stratospheric or tropospheric) offer the possibility to measure the distribution over large areas, and to study the temporal and spatial behaviour (Ahn et al., 2003; Ghude et al., 2009; Kulkarni et al., 2009a, b). Rapid urbanization and industrialization in India have made Delhi, Hyderabad and Bangalore one of the most polluted cities in this region (Gurjar

Published by Copernicus Publications on behalf of the European Geosciences Union. 


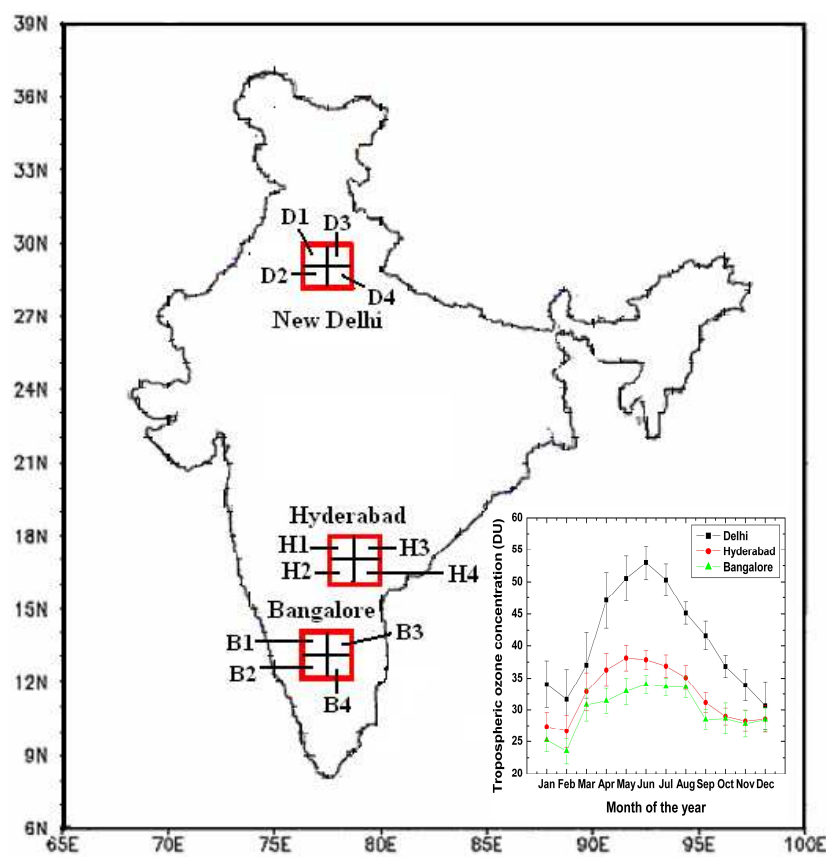

Fig. 1. Map of India with three major inland cities Delhi, Hyderabad and Bangalore with adjacent region used in this study (marked with red colour boxes). The inset shows the annual variation in averaged TOR over the three major inland cities Delhi, Hyderabad and Bangalore of India, for the period 1979-2005. The vertical bars show one sigma standard deviation.

et al., 2008). Considering the potential of large economic development in and around the major cities Delhi, Hyderabad and Bangalore, one can expect enhancement of anthropogenic activities such as increased consumption of fossil fuel and large scale industrialization. This will result in extra burden of pollution in troposphere, which can lead to further increase in ozone concentration over these cities. As a case study, in this work we analyze monthly tropospheric ozone retrieved from Total Ozone Mapping Spectrometer (TOMS) and Solar Backscatter Ultraviolet (SBUV) measurements (TOMS/SBUV) (1979-2005) to investigate temporal changes in tropospheric $\mathrm{O}_{3}$ over Delhi, Hyderabad and Bangalore. We examine the change in the climatology in tropospheric $\mathrm{O}_{3}$ between 1979-1989 and 1990-2005 and temporal distribution of $\mathrm{O}_{3}$ and trend during 1979-2005 over these cities. The most favorable situations to observe long term changes in tropospheric ozone are the places where tropospheric ozone is impacted by the local pollution, such as large cities. In this work, using multi-year observations, for the first time we have also demonstrate the TOR potential to detect temporal changes in tropospheric ozone over large cities, which are impacted by large industrial and vehicular growth.
Table 1. Characteristics of Tropospheric Ozone Residual (TOR) dataset.

\begin{tabular}{ll}
\hline $\begin{array}{l}\text { Parameter } \\
\text { Temporal coverage }\end{array}$ & $\begin{array}{l}\text { Tropospheric ozone } \\
\text { Jan 1979 to Dec 2005 } \\
\text { Temporal resolution } \\
\text { Mata gap }\end{array}$ \\
& $\begin{array}{l}\text { Monthly data } \\
\text { (Aug 1990, Mar 1991, May 1993 to }\end{array}$ \\
& Sep 1997 and Nov-Dec 1998) \\
Spatial coverage & $50^{\circ} \mathrm{S}$ to $50^{\circ} \mathrm{N}$ \\
Spatial resolution & $1.00^{\circ}$ latitude by $1.25^{\circ}$ longitude
\end{tabular}

\section{Dataset}

The ozone (TOMS/SBUV TOR) data over Delhi, Hyderabad and Bangalore have been obtained from the web site http: //asd-www.larc.nasa.gov/TOR/data.html. Table 1 presents the details about the Tropospheric Ozone Residual (TOR) data used in the present analysis. The TOR data are obtained by empirically corrected tropospheric ozone residual technique and measured in Dobson Unit (DU). The derivation of the TOR data is a two steps process. First the empirically corrected stratospheric column ozone (SCO) is calculated from SBUV profiles using the Eq. (1) (Fishman et al., 2003).

$\mathrm{SCO}=\mathrm{SBUV}$ Total $\mathrm{O}_{3}-\gamma C^{*}-\beta B^{*}-A^{*}$

Where, SBUV Total $\mathrm{O}_{3}$ is the total $\mathrm{O}_{3}$ column derived from SBUV measurements, $\gamma$ and $\beta$ lies between 0 and 1 and depends on the height of the tropopause, and $C^{*}, B^{*}$ and $A^{*}$ are empirically corrected ozone layers using SBUV profile and Logan (1999) Climatology.

Second the TOR is derived using following equation,

$\mathrm{TOR}=$ TOMS Total $\mathrm{O}_{3}-\mathrm{SCO}$

More details regarding the data retrieval methods are given in Fishman et al. (2003).

We select three major inland cities Delhi, Hyderabad and Bangalore where emission of ozone precursor's (with rapid urbanization and industrialization) are thought to have increased significantly in and around the city. Figure 1 gives the locations of these cities on a geographical map of India and inset shows tropospheric ozone climatology as a function of months over selected locations. To account for the spatial coverage, these cities have been divided into four bins, each of $1.25^{\circ}$ longitudes by $1.00^{\circ}$ latitude, and labelled D1 to $\mathrm{D} 4, \mathrm{~B} 1$ to $\mathrm{B} 4$ and $\mathrm{H} 1$ to $\mathrm{H} 4$ as shown in Fig. 1. The bins are chosen in such a way that they overlap exactly with the TOR grids. Tropospheric ozone shows strong seasonal cycle over these cities with summer maximum and winter minimum. The summer maximum (May and June) in TOR is attributed to the high solar intensity, long daylight hours, high temperature and dryer synoptic conditions (Jain et al., 2005) along with the availability of large amount of ozone precursors $\left(\mathrm{NO}_{\mathrm{x}}, \mathrm{CO}, \mathrm{VOC}\right.$ 's, etc.). This leads to photochemical 
production of ozone (Sillman et al., 1990) in the planetary boundary layer as well as in the free troposphere. During the winter period even with the availability of ozone precursors the other synoptic conditions are not favorable which results in reduced photochemical production of ozone throughout the troposphere. Therefore, lower amount of TOR is observed in the winter period. Tropospheric ozone is highest in June over Delhi ( $\sim 53$ DU) and in May over Hyderabad ( $\sim 38 \mathrm{DU})$ and Bangalore ( $\sim 34 \mathrm{DU})$. It shows minimum in December ( $\sim 31$ DU) over Delhi and in February over Hyderabad $(\sim 27 \mathrm{DU})$ and Bangalore ( $\sim 23 \mathrm{DU})$. Such a mean tropospheric $\mathrm{O}_{3}$ distribution is typical for locations in tropics and mid-latitudes (Logan, 1994; Monks, 2000; Cooper et al., 2005; Antón et al., 2010).

\section{Trends in tropospheric $\mathrm{O}_{3}$}

India was under social democratic-based policies from 1947 to 1991. Economic Liberalization began in nineties and (since 1990) India has emerged as one of the fastest-growing economies in the developing world. This lead to a significant growth in industrial, energy, transport, urban population, agriculture and service sectors. Accordingly, we have divided the total monthly TOR observation (from 1979-2005 (267 months)) into two parts; (1) before economic liberalization i.e., 1979-1989 period (132 months) and (2) from economic liberalization i.e., 1990-2005 (135 months). To examine if there was any increase in tropospheric ozone during 1990-2005, we first did frequency distribution analysis by calculating the percent change in the frequency distribution of monthly tropospheric ozone between 1979-1989 and 1990-2005 periods. Further, we compare monthly tropospheric climatology between 1979-1989 and 1990-2005. Finally, we calculated the trends in tropospheric ozone by considering monthly values from 1979-2005. We used the following algorithm to derive decadal tendency of tropospheric $\mathrm{O}_{3}$ over the cities considered in this study,

$C(\%)=f_{r a}(\%)-f_{r b}(\%)$

where, $f_{r a}(\%)$ is the relative frequency distribution (percent) for the period 1990-2005 and $f_{r b}(\%)$ is the relative frequency distribution (percent) for the period 1979-1989 for frequency intervals of $5 \mathrm{DU}$. If the output of this algorithm $(C(\%))$ is positive (negative), it shows percent increase (decrease) in respective frequency interval. Figure 2 shows frequency distribution of percentage change in the number of month of tropospheric ozone concentration for Delhi (concentration range from $20 \mathrm{DU}$ to $60 \mathrm{DU}$ ), Hyderabad and Bangalore (concentration range from $15 \mathrm{DU}$ to $45 \mathrm{DU}$ ). This figure reveals that all the three cities shows general tendency of increase in number of months with higher tropospheric ozone values during 1990-2005 period (with corresponding decrease in lower tropospheric ozone values). It can be seen that percentage change in the number of months over Delhi in

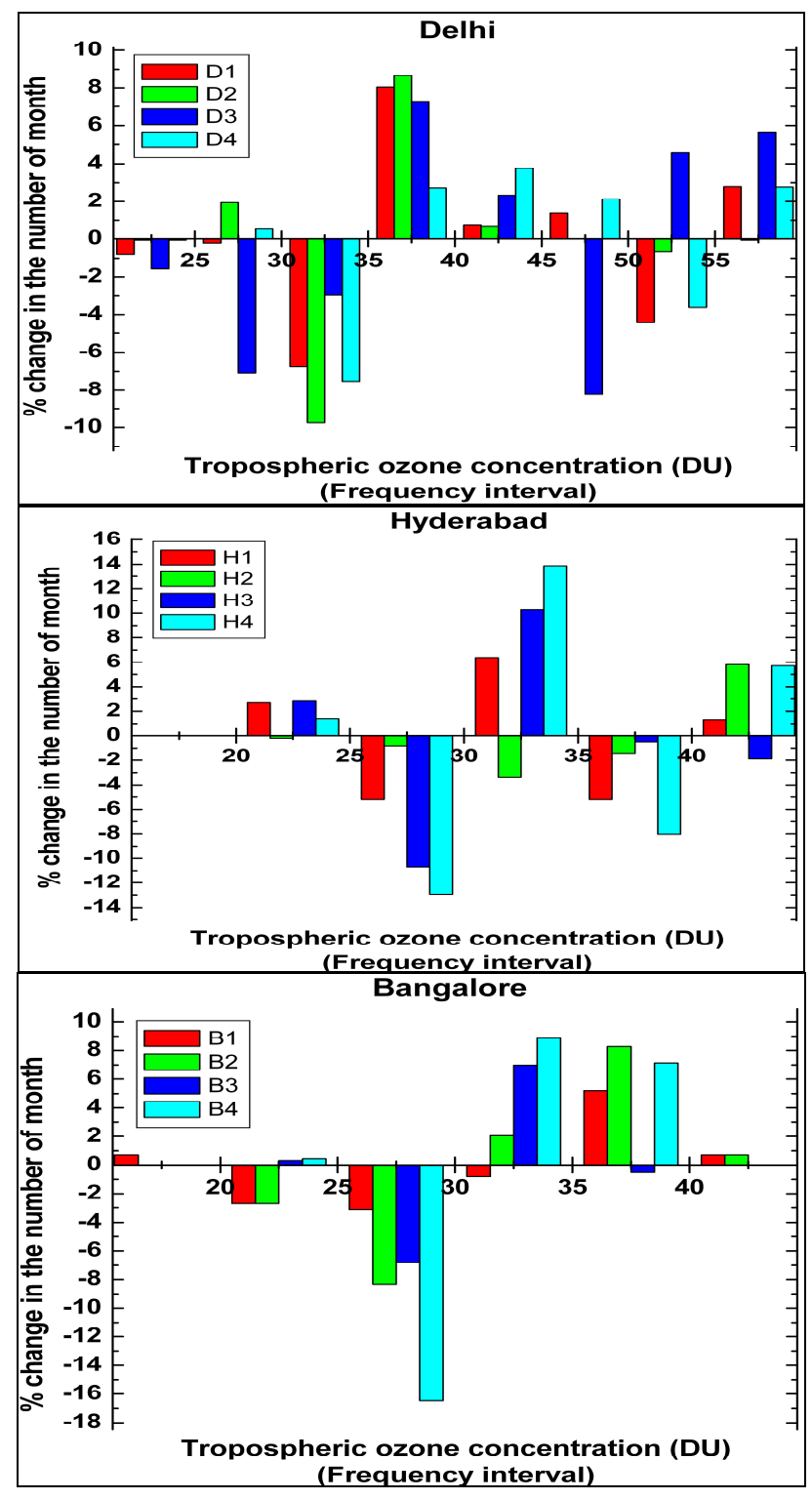

Fig. 2. Frequency distribution of $\%$ change in the number of months of tropospheric ozone concentration with frequency interval of $5 \mathrm{DU}$ in the concentration range from $20 \mathrm{DU}$ to $60 \mathrm{DU}$ over (a) Delhi and in the concentration range from $15 \mathrm{DU}$ to $60 \mathrm{DU}$ over (b) Hyderabad and (c) Bangalore.

general is negative below 35 DU frequency intervals and it is overall positive between $35-60$ DU frequency intervals. This indicates that lower tropospheric ozone values (between 20 to $35 \mathrm{DU}$ ) have decreased significantly, whereas higher tropospheric ozone values have generally increased over Delhi during 1990-2005. Similarly, percentage change in the number of months over Bangalore is negative between 15 and $30 \mathrm{DU}$ and it is evidently positive above $30 \mathrm{DU}$ frequency intervals. This clearly indicates that there is a significant increase in higher tropospheric ozone values over Bangalore 


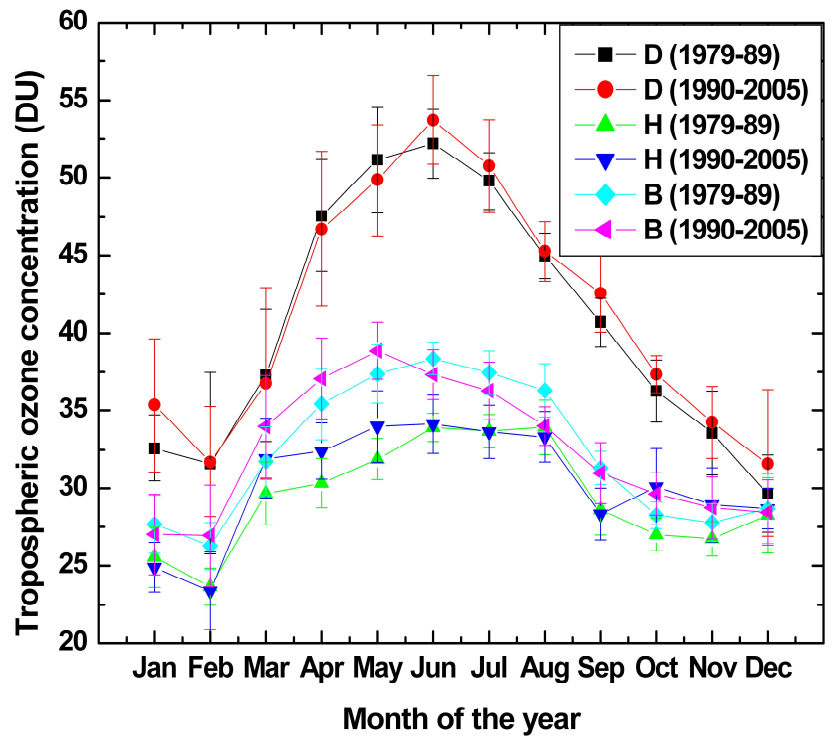

Fig. 3. Annual variation in averaged TOR over the three major inland cities Delhi, Hyderabad and Bangalore of India, for the periods 1979-1989 and 1990-2005. The vertical bars show one sigma standard deviation.

during 1990-2005. However, it can be seen from Fig. 2 that over Hyderabad percentage change in the number of months is positive for frequency intervals between 20-25 DU, 30 $35 \mathrm{DU}$ and $40-45 \mathrm{DU}$, whereas it is negative for frequency intervals between 23-30 DU and 35-40 DU. Although, systematic change in tropospheric ozone values over Hyderabad is not seen during 1990-2005, general tendency of frequency distribution shows that there is noticeable increase in the higher tropospheric values (40-45 DU). This analysis thus provides useful information on the changes in the tropospheric ozone over the selected cities during 1990-2005 with respect to 1979-1989. Inspection of Fig. 2 clearly reveals that higher and extreme tropospheric ozone values over Delhi, Hyderabad and Bangalore significantly increased during 1990-2005 compared to 1979-1989.

To see if there is change in the tropospheric ozone levels during 1990-2005, in Fig. 3 we compare the tropospheric ozone climatology between 1979-1989 and 1990-2005 for all the three cities considered in this study. It shows little evidence of long-term changes in the tropospheric ozone over all the cities. Inspection of Fig. 3 reveals that the increase in tropospheric ozone was not seen for all the seasons over Delhi, Hyderabad and Bangalore. A comparison of tropospheric ozone over Delhi in particular show noticeable increase in ozone amount during monsoon (JJAS), postmonsoon (ON) and winter months (NDJ) in 1990-2005 period. It does not show such an increase in ozone levels during pre-monsoon (MAM) months, rather shows slight decrease. In contrast, tropospheric ozone levels over Hyderabad and Bangalore in 1990-2005 show marked increases during pre-monsoon (MAM) months and do not show such an increase in winter months. Similar to Delhi, it also shows marked increases over Hyderabad and Bangalore during post-monsoon season. During monsoon tropospheric ozone levels over Bangalore do not show evidence of significant change. However, a noticeable decrease in tropospheric ozone levels during monsoon is seen over Hyderabad during 1990-2005. Although Figs. 2 and 3 show little evidence of long term changes, this result suggests that the tropospheric ozone levels over these cities appeared to be influenced by the increased anthropogenic activities in and around the city. Chandra et al. (1999) estimated the changes in tropospheric ozone over 11-year solar cycle (minimum to maximum) using Ottawa monthly-mean F10.7 cm solar flux (standard flux units ( $2.8 \mathrm{GHz}$ frequency), which is apparently more closely related to solar ultraviolet flux). They found mean annual solar response for tropospheric ozone of about $-9( \pm 3) \%$ $(-2.29 \pm 1.01 \mathrm{DU})$ for an increase 100 units of $\mathrm{F} 10.7 \mathrm{~cm}$ flux. We observed that the change in F10.7 cm flux before and after 1990 was about 11.04 units at F10.7 cm flux. This change is primarily driven by the division of monthly mean solar cycle time-series before and after 1990 (between the period 1979 and 2005). Therefore, decrease of about $\sim 11$ units of F10.7 cm flux after 1990 may increase tropospheric ozone by less than $1 \%$. However, the difference observed in tropospheric ozone before and after 1990 is more that 3\% (Fig. 3) over the cities considered in our study. Therefore, we feel that the effect of changes in short wave radiation before after 1990 on TOR changes would be small.

To examine if there was any long-term trends in tropospheric ozone over these cities we did regression analysis of tropospheric ozone using trend model, details of which are given elsewhere (Ziemke et al., 1997) and hence described here briefly. Error estimates are according to Neter et al. (1985). In order to remove the effects of natural sources of ozone variability such as 11-year solar cycle as well as the linear trend in solar irradiance we use a regression model. It consists of seasonal cycle, linear trend and solar cycle. The general expression for the regression model equation can be written as follows:

$\theta(t)=\alpha(t)+\beta(t)$.Trend $(t)+\delta(t)$. Solar $(t)+\operatorname{resid}(t)$

Where $\alpha(t)$ and $\beta(t)$ are the time-dependent 12-month seasonal and trend coefficients, respectively and $\delta(t)$ is 12 month coefficients corresponding to the ozone driving quantities such as solar flux. Solar $(t)$ is solar time series proxy which is used in an effort to reduce errors in local ozone trends. Solar proxies have been used for Ottawa monthlymean F10.7 cm solar flux (standard flux units $(2.8 \mathrm{GHz}$ frequency)) from January 1979 to December 2005 (ftp://ftp. ngdc.noaa.gov/), which is apparently more closely related to solar ultraviolet flux used in the model as solar proxy indices. resid $(t)$ represents the residues, or noise. Monthly mean tropospheric ozone over the cities (for each bean) from 1979-2005 are used to obtained the time series. These time 
Table 2. Trend regression coefficients (\% per year) for tropospheric ozone residue (TOR) over the three tropical inland cities Delhi, Hyderabad and Bangalore for the period 1979-2005.

\begin{tabular}{lcccccc}
\hline Seasons & \multicolumn{2}{c}{ Delhi } & \multicolumn{2}{c}{ Hyderabad } & \multicolumn{2}{c}{ Bangalore } \\
& Trend $\left(\% \mathrm{y}^{-1}\right)$ & $2 \sigma( \pm)$ & Trend $\left(\% \mathrm{y}^{-1}\right)$ & $2 \sigma( \pm)$ & Trend $\left(\% \mathrm{y}^{-1}\right)$ & $2 \sigma( \pm)$ \\
\hline Pre-monsoon (MAM) & 0.04 & 0.3 & 0.47 & 0.25 & 0.50 & 0.27 \\
Monsoon (JJAS) & 0.34 & 0.2 & -0.03 & 0.16 & 0.20 & 0.26 \\
Post-monsoon (ON) & 0.32 & 0.3 & 0.34 & 0.2 & 0.78 & 0.3 \\
Winter (DJF) & 0.56 & 0.48 & 0.05 & 0.22 & 0.13 & 0.3 \\
\hline
\end{tabular}

series are then subjected to the multifunctional regression model. Monthly trend coefficients obtained from the model (for a bin) are then averaged to get a seasonal trend coefficient. Similarly, corresponding monthly two-sigma error values are averaged to get a seasonal two-sigma error estimate. Seasonal trend coefficients are obtained separately for each bin shown in Fig. 1. Table 2 shows trends for Delhi (B3), Hyderabad (H2) and Bangalore (B2) for four seasons. The four seasons considered are as per the India Meteorological Department (IMD) (MOEF, 2004): winter from December-January-February; pre-monsoon or summer from March-April-May; monsoon from June-July-AugustSeptember and post-monsoon from October-November. Annually, positive but insignificant trends of about $3.1 \pm 3.2(2 \sigma)$ $\%$ and $2 \pm 2(2 \sigma) \%$ per decade are found over Delhi and Hyderabad, respectively. A tropospheric ozone level over Bangalore, however, shows a trend close to significance $(4 \pm 2.8(2 \sigma) \%$ per decade) during 1979-2005. Trend obtained from the model shows significant change during monsoon over Delhi $(+3.4 \pm 2(2 \sigma) \%$ per decade), during premonsoon over Hyderabad $(+4.7 \pm 2.5(2 \sigma) \%$ per decade $)$ and Bangalore $(+5 \pm 2.7(2 \sigma) \%$ per decade). It also shows significant change over Hyderabad $(+3.4 \pm 2(2 \sigma) \%$ per decade) and Bangalore $(+7.8 \pm 2(3 \sigma) \%$ per decade $)$, and positive but insignificant trend of about $3.2 \pm 3(2 \sigma) \%$ during post-monsoon season. The highest trend is seen over Bangalore despite the fact that growth in urban and vehicular population is less compared to Delhi (Table 3).

This increase in trend is believed to be a result of increased anthropogenic emission in and around Delhi, Hyderabad and Bangalore. Beig and Brasseure (2006) showed that CO emission from Delhi, Hyderabad and Bangalore have increased by approximately 35\%, 25\% and 20\% respectively between 1991 and 2001. Similarly, $\mathrm{NO}_{\mathrm{x}}$ emissions from Delhi have increased by more that $100 \%$ and from Hyderabad and Bangalore it is increased by approximately 65\% (http://htap.org/meetings/2008/2008_10/HTAP\% 20Hanoi20Presentations/Posters/Ghude.pdf). Power stations, road transport, industries, use of coal for domestic purposes and burning of fossil fuels are the major sources of air pollution in these cities (Gurjar et al., 2004). The rapid growth of economical activities in Delhi, Hyderabad
Table 3. Urban and vehicular population in 1981, 1991 and 2001.

\begin{tabular}{|c|c|c|c|}
\hline & Delhi & Hyderabad & Bangalore \\
\hline & \multicolumn{3}{|c|}{ Population (in lakhs) $)^{\mathrm{a}}$} \\
\hline 1981 & 57 & 25 & 29 \\
\hline 1991 & 84 & 42 & 41 \\
\hline 2001 & 128 & 57 & 57 \\
\hline \multicolumn{4}{|c|}{ Vehicular population (in thousands) } \\
\hline $1981^{b}$ & 536 & 89 & 175 \\
\hline $1991^{b}$ & 1831 & 443 & 577 \\
\hline 2001 & $3456^{\mathrm{c}}$ & $1450^{\mathrm{d}}$ & $1950^{\mathrm{e}}$ \\
\hline
\end{tabular}

${ }^{a}$ www.iipsenvis.nic.in, ${ }^{b}$ Ramanathan (2000), ${ }^{c}$ www.delhiplanning.nic.in, ${ }^{d}$ Gertler et al. (2009), ${ }^{\text {e }}$ Sabapathy (2008)

and Bangalore in recent times has resulted in significant increase in industrial and vehicular activities in and around these cities. Table 3 gives overview of urban and vehicular population during 1981-2001 periods. It can be seen that rapid increase in urban population a number of vehicles occurred during 1981-2001. This resulted in significant changes in anthropogenic emission during the study period (Garg et al., 2001).

\section{Conclusion}

In this work we analyze troposphere ozone residual data from 1979-2005 to examine the change in tropospheric ozone before and after 1990 over inland cities Delhi, Hyderabad and Bangalore. A frequency distribution of data before and after 1990 shows that there is noticeable tendency of increase in the higher tropospheric values after 1990. Further, a comparison of tropospheric ozone climatology before and after 1990 over these cities shows evidence of increase in the tropospheric ozone after 1990. Finally, to examine if there were any long-term trends in tropospheric ozone over these cities we did regression analysis of tropospheric ozone. Trend obtained from the model shows significant change during monsoon over Delhi, during pre-monsoon and post-monsoon over Hyderabad and Bangalore. These results 
suggest that tropospheric ozone levels over industrial cities Delhi, Hyderabad and Bangalore appeared to be influenced by the increased anthropogenic activities in and around the city.

The source of uncertainty in the long-term records of tropospheric ozone residue could be because of (a) the inconsistency between instruments (TOMS and SBUV) or tropopause height information, which is derived from a reanalysis of the meteorological data from NCEP and (b) degradation of the scanning mirror on the EP-TOMS instrument occurring from the year 2000 onwards. More importantly, the shapes to the ozone profiles derived from the SBUV must be examined in the vicinity of the tropopause over this entire period to ensure that no secular changes evolve during this time (Fishman et al., 2003). Much work has gone into making sure the TOMS total ozone data are consistent between instruments. The SBUV is taken from at least four different instruments on different satellites. Although care is taken to provide a consistent data set between the four instruments, which is done for the total ozone columns. Careful analysis of the ozone amounts in the lower stratosphere is done for making sure they were as good as possible, because errors in this region of the atmosphere would greatly discredit any conclusions about the TOR (Fishman et al., 2003). Wozniak et al. (2005) conducted a thorough study of the stratospheric column ozone (SCO) amounts that are generated by the residual technique and used SAGE profiles to assure that use of SBUV for deriving TOR was justifiable. However, it is important to look into detail as to weather or not there are differences in the way these tropopause height analyses were made over the 30 -year period and trend analysis of the calculated SCO to reduce the uncertainty in the long-term TOR data. Detailed analysis by Anton et al. (2010) shows that the degradation of the scanning mirror on the EP-TOMS instrument underestimates total column ozone measured by ground based Brewer and Dobson spectrophotometers by $\sim 1$ to $3 \%$. This negative bias implies that the TOR values are underestimated and adds to uncertainties in the trend information. This information will reduce the uncertainties in the trend information in the TOR data and needs to explore further. In conclusion it can be stated that the results obtained in this paper provide first hand information on tropospheric trends over the big tropical Indian cities, which has seen large industrial and vehicular growth after 1990s. It should be emphasized that although the present analysis using tropospheric ozone residual technique might influence the magnitude of the trend coefficients, we believe that it would not affect the general qualitative nature of the trend results.

Acknowledgements. Author (Pavan S. Kulkarni) is thankful to Geophysics Centre of the University of Evora (CGE-UE) for the fellowship in the project "SPATRAM-MIGE Polar Project", funded by the Portuguese Science Foundation - FCT. Author (Sachin D. Ghude) is thankful to the Director, Indian Institute of Tropical Meteorology for encouragement during the progress of the work. Thanks are also due to "TROPOSPHERIC OZONE RESIDUAL (TOR) HOMEPAGE" for the tropospheric ozone residual (TOR) data.

Topical Editor P. M. Ruti thanks one anonymous referee for her/his help in evaluating this paper.

\section{References}

Ahn, C., Ziemke, J. R., Chandra, S., and Bhartia, P. K.: Derivation of tropospheric column ozone from the Earth Probe TOMS/GOES co-located data sets using the cloud slicing technique, J. Atmos. Solar-Terr. Phys., 65, 1127-1137, 2003.

Akimoto, H., Nakane, H., and Matsumoto, Y.: The chemistry of oxidant generation: tropospheric ozone increase in Japan, in: Chemistry of the Atmosphere: The Impact on Global Change, Calvert, J., Blackwell Scientific Publications, Oxford, UK, 261273, 1994.

Antón, M., López, M., Serrano, A., Bañón, M., and García, J. A.: Diurnal variability of total ozone column over Madrid (Spain), Atmos. Environ., 44, 2793-2798, 2010.

Antón, M., Koukouli, M. E., Kroon, M., McPeters, R. D., Labow, G. J., Balis, D., and Serrano, A.: Global validation of empirically corrected EP-TOMS total ozone columns using Brewer and Dobson ground-based measurements, J. Geophys. Res., 115, D19305, doi:10.1029/2010JD014178, 2010.

Beig, G., Ghude, S. D., Polade, S. D., and Tyagi, B.: Threshold exceedances and cumulative ozone exposure indices at tropical suburban site, Geophys. Res. Lett., 35, L02802, doi:10.1029/2007GL031434, 2008.

Beig, G. and Brasseur, G. P.: Influence of anthropogenic emissions on tropospheric ozone and its precursors over the Indian tropical region during a Monsoon, Geophys. Res. Lett., 33, L07808, doi:10.1029/2005GL024949, 2006.

Chandra, S., Ziemke, J. R., and Stewart, R. W.: An 11-year solarcycle in tropospheric ozone from TOMS measurements, Geophys. Res. Lett., 26, 185-188, 1999.

Cooper, O. R., Stohl, A., Eckhardt, S., Parrish, D. D., Oltmans, S. J., Johnson, B. J., Nedelec, P., Schmidlin, F. J., Newchurch, M. J., Kondo, Y., and Kita, K.: A springtime comparison of tropospheric ozone and transport pathways on the east and west coasts of the United States, J. Geophys. Res., 110, D05S90, doi:10.1029/2004JD005183, 2005.

Fishman, J., Wozniak, A. E., and Creilson, J. K.: Global distribution of tropospheric ozone from satellite measurements using the empirically corrected tropospheric ozone residual technique: Identification of the regional aspects of air pollution, Atmos. Chem. Phys., 3, 893-907, doi:10.5194/acp-3-893-2003, 2003.

Garg, A., Shukla, P. R., Bhattacharya, S., and Dadhwal, V. K.: Subregion (district) and sector level $\mathrm{SO} 2$ and $\mathrm{NOx}$ emissions for India: assessment of inventories and mitigation flexibility, Atmos. Environ., 35, 703-713, 2001.

Gertler, A., Guttikunda, S., and Koppaka, R.: The Impact of the Transport Sector on PM Levels in Hyderabad, India, in: Proceedings of the International symposium Environment and Transport in different contexts, Ghardaïa, Algeria, India, 16-18 February, 2009, 15-21, 2009.

Ghude, S. D., Kulkarni, P. S., Beig, G., Jain, S. L., and Arya, B. C.: Global distribution of tropospheric ozone and its precursors: a view from the space, Int. J. Remote Sensing, 31(02), 485-495, doi:10.1080/01431160902893519, 2010. 
Ghude, S. D., Lal, D. M., Beig, G., Vander A, R. J., and Sabale, D.: Rain-induced soil $\mathrm{NO}_{X}$ emission from India during onset of the summer monsoon: A satellite perspective, J. Geophys. Res., 115, D16304, doi:10.1029/2009JD013367, 2010.

Ghude, S. D., Jain, S. L., Arya, B. C., Kulkarni, P. S., Kumar, A., and Ahammed, N.: Temporal and Spatial Variability of Surface Ozone at Delhi and Antarctica, Int. J. Climatol., 26, 1367-1382, 2006.

Ghude, S. D., Jain, S. L., Beig, G., Arya, B. C., Ahammed, Y. N., Arun Kumar and Bhisma Tyagi.: Ozone in ambient air at tropical mega city, Delhi: characteristics, trends and cumulative ozone exposure indices, J. Atmos. Chem., 60, 237-252, doi:10.1007/s10874-009-9119-4, 2009.

Ghude, S. D., Fadnavis, S., Beig, G., Vander A, R. J., and Polade, S. D.: Detection of surface emission hotspots, trends and seasonal cycle from satellites retrieved $\mathrm{NO}_{2}$ over India, J. Geophys. Res., 113, D20305, 2008.

Ghude, S. D., Vander A, R. J., Bieg, G., Fadnavis, S., and Polade, S. D.: Global distribution of tropospheric $\mathrm{NO}_{2}$ and its trend during past decade over major source regions, Environ. Pollut., 9, 52535260, doi:10.1016/j.envpol.2009.01.013, 2009a.

Gurjar, B. R., van Aardenne, J. A., Lelieveld, J., and Mohan, M.: Emission estimates and trends (1990-2000) for megacity Delhi and implications, Atmos. Environ., 38(33), 5663-5681, doi:10.1016/j.atmosenv.2004.05.057, 2004.

Gurjar, B. R., Butler, T. M., Lawrence, M. G., and Lelieveld, J.: Evaluation of Emissions and Air Quality in Megacities, Atmos. Environ., 42(7), 1593-1606, doi:10.1016/j.atmosenv.2007.10.048, 2008

Motor vehicle population in Delhi: http://delhiplanning.nic.in/ Economic\%20Survey/Ecosur2001-02/PDF/chap12(table).PDF, 3 May 2010.

LRTAP: http://htap.org/meetings/2008, 7 May 2010.

Distribution of Population, Literacy, Sex Ratio, Workers \& Non-Workers by sex-wise for Major Cities in India, 1981-2001: http://www.iipsenvis.nic.in/SDNP_ENVIS_ Program/DataSheets/datasheet7.pdf, 9 May 2010.

Jain, S. L., Arya, B. C., Kumar, A., Ghude, S. D., and Kulkarni, P. S.: Observational Study of Surface Ozone at New Delhi, India, Int. J. Remote Sensing, 26, 3515-3526, 2005.

Klumpp, A., Ansel, W., Klumpp, G., Calatayud, V., Garrec, J. P., He, S., Pe nuelas, J., Ribas, A., Ro-Poulsen, H., Rasmussen, S., Sanz, M. J., and Vergne, P.: Ozone pollution and ozone biomonitoring in European cities. Part I: Ozone concentrations and cumulative exposure indices at urban and suburban sites, Atmos. Environ., 40, 7963-7974, 2006.

Kulkarni, P. S., Jain, S. L., Ghude, S. D., Arya, B. C., Dubey, P. K., and Shahnawaz, On some aspects of tropospheric ozone variability over the Indo-Gangetic (IG) basin, India, Int. J. Remote Sensing, 30(15-16), 4111-4122, 2009a.

Kulkarni, P. S., Ghude, S. D., Jain, S. L., Arya, B. C., Dubey, P. K., and Shahnawaz, Tropospheric ozone variability over the Indian coastline and adjacent land and sea, Int. J. Remote Sensing, in press, 2009b.

Lal, S., Naja, M., and Subbaraya, B. H.: Seasonal variations in surface ozone and its precursors over an urban site in India, Atmos. Environ., 34, 2713-2724, 2000.
Liu, S. C. and Trainer, M.: Response of the tropospheric ozone and odd hydrogen radicals to column ozone change, J. Atmos. Chem., 6, 221-233, 1987.

Logan, J. A.: Tropospheric ozone: Seasonal behavior, trends and anthropogenic influence, J.Geophys. Res., 90, 10463-10482, 1985.

Logan, J. A.: Trends in vertical distribution of ozone: An analysis of ozonesonde data, J.Geophys. Res., 99, 25555-25585, 1994.

Logan, J. A.: An analysis of ozonesonde data for the troposphere: Recommendations for testing 3-D models, and development of a gridded climatology for tropospheric ozone, J. Geophys. Res., 104, 16115-16149, 1999.

Mickley, L. J., Murti, P. P., Jacob, D. J., Logan, J. A., Koch, D. M., and Rind, D.: Radiative forcing from tropospheric ozone calculated with a unified chemistry-climate model, J. Geophys. Res., 104, 30153-30172, 2001.

MOEF: India's Initial National Communication to the United Nations Framework Convention on Climate Change, Chapter 1, 4, Ministry of Environment and Forest, Government of India, 2004.

Monks, P. S.: A review of the observations and origins of the spring ozone maximum, Atmos. Environ., 34, 3545-3561, 2000.

Naja. M. and Lal, S.: Surface ozone and precursor gases at Gadanki $\left(13.5^{\circ} \mathrm{N}, 79.2^{\circ} \mathrm{E}\right)$, a tropical rural site in India, J. Geophys. Res., 107(D14), 4197, doi:10.1029/2001JD000357, 2002.

Neter, J., Wasserman, W., and Kutner, M. H.: Applied linear statistical models. Irwin, Homewood, IL, 1985.

Oltmans, S. J., Lefohn, A. S., Scheel, H. E., Harris, J. M., Levy II, H., Galbally, I. E., Brunke, E. G., Meyer, C. P., Lathrop, J. A., Johnson, B. J., Shadwick, D. S., Cuevas, E., Schmidlin, F. J., Tarasick, D. W., Claude, H., Kerr, J. B., Uchino, O., and Mohnen, V.: Trends of ozone in the troposphere, Geophys. Res. Lett., 25, 139-142, 1998.

Pochanart, P., Akimoto, H., Kinjo, Y., and Tanimoto, H.: Surface ozone at four remote island sites and the preliminary assessment of the exceedances of its critical level in Japan, Atmos. Environ., 36, 4235-4250, 2002.

Ramanathan, R.: Link between population and number of vehicles: Evidence from Indian cities, Cities, 17(4), 263-269, 2000.

Sabapathy, A.: Air quality outcomes of fuel quality and vehicular technology improvements in Bangalore city, India, Transportation Research Part D: Transport and Environment, 13(7), 449454, 2008.

Sillman, S., Logan, J. A., and Wofsy, S. C.: The sensitivity of ozone to nitrogen oxides and hydrocarbons in regional ozone episodes. J. Geophys. Res., 95, 1837-1851, 1990.

Wozniak, A. E., Fishman, J., Wang, P.-H., and Creilson, J. K.: Distribution of stratospheric column ozone (SCO) determined from satellite observations: Validation of solar backscattered ultraviolet (SBUV) measurements in support of the tropospheric ozone residual (TOR) method, J. Geophys. Res., 110, D20305, doi:10.1029/2005JD005842, 2005.

Ziemke, J. R., Chandra, S., McPeters, R. D., and Newman, P. A.: Dynamical proxies of column ozone with applications to global trend models, J. Geophys. Res. 102, 6117-6129, 1997. 